\title{
Race as a Cause for Discrimination and "Othering", Bernard Malamud's The Tenants a Case Study
}

\author{
Mohammareza Ghanbarinajjar ${ }^{1}$ \\ ${ }^{1}$ English Department, Jouybar Branch, Islamic Azad University, Iran \\ Correspondence: Mohammareza Ghanbarinajjar, English Department, Jouybar Branch, Islamic Azad University, \\ Mazandaran, Iran. Tel: 98-911-313-9611. E-mail: ghanbari1973@yahoo.com
}

Received: February 20, 2013 Accepted: March 18, 2013 Online Published: April 26, 2013

doi:10.5539/ells.v3n2p1 URL: http://dx.doi.org/10.5539/ells.v3n2p1

\begin{abstract}
The notion of discrimination and Othering acted upon people with different religious belief or race is as old as the human race itself. But the fact is that in modern times science even fueled the problem by presenting human hierarchy and the idea of superiority or inferiority of one race over the other. As a social phenomenon this issue entered into the realm of literary studies after it had been overtly or covertly used in literary works to foreground the problem. Bernard Malamud's The Tenants deals with the conflict between two minority groups, Blacks and Jews, in American society. Emphasizing on the fact that physical features and religious belief are reasons for being treated as Other even in the most liberal society, Malamud indicates that the world has never been a Utopia and advances in science and technology did not eliminate racism and discrimination from society but they helped them change from one form to another.
\end{abstract}

Keywords: race, discrimination, Othering, Bernard Malamud, The Tenants

\section{Introduction}

One definition of the race is those who "had a long shared history; cultural traditions of their own; a common geographical origin (or descent from a small number of common ancestors); a common language; a common literature; a common religion; and they were a minority or a majority within a larger community" (Rattansi, 2007, p. 87).

Science has often been used as a justification to propose, and enact racist social policies. The philosophical and political underpinning of ideas associated with racial superiority and inferiority were first given scientific legitimacy and credence with the publication of Charles Darwin's (1859) revolutionary book, The Origin of Species (Dennis, 1995). The scientific thought of the Enlightenment was a precondition for the growth of a modern racism based on physical typology. In 1735, the great Swedish naturalist Carl Linnaeus included humans as a species within the primate genus and then attempted to divide that species into varieties. This early stab at the scientific classification of human types included some mythical and "monstrous" creatures; but the durable heart of the schema was the differentiation Linnaeus made among Europeans, American Indians, Asians, and Africans. Although he did not explicitly rank them, Linnaeus's descriptions of the races clearly indicated his preferences. One example is Linne's theory that categorized human races as follows:

- Americans: reddish, obstinate, regulated by custom

- Europeans: white, gentle, and governed by laws

- Asians: yellow, sever and ruled by opinion

The common perception of racism identifies it with segregation, apartheid, overt discrimination, racial violence, blatant prejudice, white supremacism or right-wing activism. we should not forget either that, despite its specific social and historical nature, this postwar European racism continues a long tradition of "Eurocentrism" and racism, which goes back to the role of Europeans in the conquest, enslavement, colonization and genocide of Africans, Asians and other indigenous peoples.

Experiences by people from minority groups and scholarly research show that racism is exhibited in many daily acts of discrimination and prejudice viz in processes of marginalization, exclusion or problematization. The daily interaction between "whites" and "blacks" (or other minorities) in public places, businesses, factories, offices, 
police stations, court rooms, class rooms, news rooms and other locations, is riddled with the micro-inequities that characterize ethnic or racial subordination. "Aggression, abuse, lack of respect, indifference, exclusion, underestimating, accusations and discrediting are some of the many daily manifestations of racism" (Dijk, 1992, p. 19).

\section{Materials and Methods}

In this study the researcher tries to analyze Bernard Malamud's The Tenants in the light of cultural and political studies. Since, especially in the second half of twentieth century, cultural studies encompass the literary, social, and political realms. Moreover, this approach has given the researcher the opportunity to find the formidable relationship between race and religion issues with the focus on the "Othering" which has never been studied in Malamud's works so far. The article examines how Otherness and marginality are articulated in The Tenants by Bernard Malamud. The researcher also tries to focus on the following questions and by analyzing and reviewing Malamud's work finds the appropriate answer for each of them. May Malamud's novel, with its theme of racial antagonism in the United States, as well as its reflection on the varieties of literary forms of expression, be seen as anticipating the multiculturalism and canon debates of modern American society? Should Malamud's work thus be seen merely as problematic, commenting on the current state of affairs, or perhaps also as somewhat prophetic, attempting a prognosis, whatever its accuracy, of future developments? What are the key features of Othering? How does the novel show the conflicting relationship between Black and Jew? What does the text reveal about the assimilation or resistance of the minority groups?

In doing so Bernard Malamud's The Tenants will be used as primary source and some other books, articles and reviews as secondary sources.

\section{Discussion}

Race as a cause for trouble for nations and individuals is not a new subject of phenomenon. But what made it possible is the discourse led by white race with the collaboration of the European scientists. This discourse paved the way for a belief that people with certain physical and biological characteristics are superior to others. Then categorizing people with so called scientific criterion made one race (white) superior and the other (black) inferior to other races.

This categorization and discourse led to white supremacy and made it as the most cultured, logical and dignified race and the black race as barbaric, uncultured and governed by sexual ride, therefore a victim for any possible troubles. Though modern scientists disapproved the scientific supremacy of the white race, the practice of racism and racial discrimination in modern society is still obvious and backed by political parties, institutions or right-wing activists.

Though modern scientists disapproved the scientific supremacy of the white race, the practice of racism and racial discrimination in modern society is still obvious and backed by political parties, institutions or even governments.

Despite his other works, in The Tenants Malamud depicts two groups of characters both minority and marginalized, one group for his physical features, and the other for his religious belief. The novel deals with the issue of black anti-Jewish propensity in the 1960s, despite the fact that Jews supported various black groups and causes and some Jews had played a particularly prominent part in the black civil rights movement of the fifties. Leslie Fiedler (1977) says that "Jews are the only white Americans who might feel no guilt toward blacks since they neither owned slaves nor had any part in lynchings" (103). Moreover, Jews can see in blacks a people who are treated as they themselves once were.

When Malamud was asked why he wrote The Tenants, he answered, "Jews and blacks, the period of the troubles in New York City, the teachers strike, the rise of black activism, the mix-up of cause and effect. I thought I'd say a word (Stern, 1975)." When he wrote The Tenants, Malamud was addressing a subject that was central to his place and time while attempting to employ it for his own fictional purposes. "The Tenants was written to make a social difference in the contemporary world -- to bring about a greater understanding of the black and white races such as Malamud believed had only previously been achieved by William Faulkner" (Davis, 2007, p. 267).

As far as the novel and the black character Willie is concerned Ozick (1975) says that Malamud "did not make Willie. He borrowed him - he mimicked him - from the literature and the politics of the black movement. Willie is the black dream that is current in our world. Blacks made him. Few blacks disavow him" (p. 90).

Black anti-Semitism was fueled by the fact that the people who owned the shops and the buildings in cities where they lived or migrated were sometimes Jewish. Blacks accused Jews of gouging them for unjust rents and making them pay high prices for food. 
Malamud told Alan Forrest: "It is a great pity that two groups of people, each with an identical history of persecution, are living together with that amount of antagonism. One can only hope that eventually they will recognize each other's history and come together." The mutually exacerbating reactions of white upon black and black upon white arising out of the original injustice of inequality.

Physical features such as skin color, shape of nose, shape of lips, size of skull, and type of hair are only a few noticeable signifiers that can make a person seem different in a community or society. The fact that how people who are spotted as Other in a community are treated badly has never been fixed, rather highly dependant to the time and place and the people directly involved with the issue. Evidences indicate that the world has never been Utopia to home people with differences in peace; but the type and strictness of cruelty against Others might have changed during the time. My emphasis is that even in modern time with considerable advances in science and technology and having educated and cultured people all around us discrimination and brutality against Others have not abolished but they appears in new forms.

A cold, chilly, and snowy atmosphere spread its dullness and motionlessness over the whole novel. This morose epoch entombed the characters in their so called habitat which is a total wreck and boosted the misery and pity. The major characters of the novel based on their role can be grouped into two pairs, Harry Lesser and Irene are white are Jew but Willie and Mary are black. The other people in the novel are Levenspiel, the Jew landlord, and a number of black youngsters who are friends to Willie.

People of minority use literature and art to show the historical evidences, to express their feeling toward the oppressors and at the same time to present their hope and dream for the future. "...their literature is not that of assimilation, but in many ways that of establishing difference, separatism, and cultural resistance." "Willie has discovered writing as a social and political tool. The end of his tracts must be that of social protest: with an attack on what he personally perceives as white mainstream society he wishes to expose its deficiencies and call attention to his own plight." (Malamud, 1972) ${ }^{1}$

Irene says that "The more he writes the blacker he becomes (93)." Because in his writings he remembers and expresses more of being black and different from other people. "Instead of an integration into the literary and artistic mainstream (as many Jewish authors felt necessary and desirable), black writers and artists wanted, especially since the Black Arts Movement of the 1960s, to arrive at their "own" forms of literary expression which would have direct relevance for their lives" (Spevack, 1997, p. 33).

Regardless of the rivalry between Harry and Willie as writers, Willie asks to read his chapters and have his ideas. Harry finds the writing raw and not stylish but he is wondering how to tell him what he thinks about his writing. He thinks of letting know in a form note or letter. He makes his mind to tell him. He tries to prepare the condition and also make Willie ready to face the reality about his work, though he knows that it is not easy to embrace it. Willie gets angry and tries to defend and at last comes to this pint that there is a big and fundamental difference in black and white, their life, and their writings.

In cold and haughty anger the black replies. "No ofay motherfucker can put himself in my place. This is a black book we talkin about that you don't understand at all. White fiction ain't the same as black. It can't be."

"You can't turn black experience into literature just writing it down."

"Black ain't white and never can be. It is once and for all only black. It ain't universal if that's what you are hintin up to. What I feel you feel different. You can't write about black because you don't have the least idea what we are or how we feel. Our feelin chemistry is different than you. Dig that? It has to be so. I'm writin the soul writin of black people cryin out we are still slaves in this fuckn country and we ain't gonna stay slaves any longer. How can you understand it, Lesser, if your brain is white?"

"So is your brain white. But if the experience is about being human and moves me then you've made it my experience. You created it for me. You can deny universality, Willie, but you can't abolish it."

"Bein human is shit. It don't give you any privileges, it never gave us any."

'If we're talking about art, form demands its rights, or there's no order and maybe no meaning. What else there isn't I think you know.'

'Art can kiss my juicy ass. You want to know what's really art? I am art. Willie Spearmint, black man. My form is myself' (60-61).

Harry suggests him to give it to a publisher and get someone else's opinion but Willie expresses what he think of white think of black "Because I tried ten of those rat-brained Jews and they all turned it down for a lot of horseshit reasons, because they are afraid of what the book says" (61). 
What I said about revising some of my ideas don't mean I'm changing how I feel on black writing in comparison to white. Art is O.K. when it helps you to say what you got to, but I dont want to turn into a halfass white writer or an ass-kissing Neegro who imitates ofays because he ashamed or afraid to be black. I write black because I am black and what I got to say means something different to black people than it does to whites, if you dig. We think different than you do, Lesser. We do and we are, and we write different. If some white prick tears a piece of black skin off your ass every day, when somebody says, 'Sit down,' it's gonna mean two different things to me and you, and that's why black fiction has got to be different than white. The words make it different because the experience does. You know that, man. Also we are the rising people of the future, and if the whites try to hold us down it ain't no secret we might have to cut your throats. You have had your day and now we are gonna have ours. That's what I got to write about but I want to write it in black art, in the best way I can. In other words, Lesser, I want to know what you know and _add on to that_what I know _because_ I am black. And if that means I have to learn something from whitey to do it better as a black man, then I will for that purpose only (76-77).

If society in the whole can be considered as a macrocosm and multicultural such as what we find in The Tenants, people who share the same physical, social, and cultural features and beliefs find out themselves settled in the same neighborhood and form smaller communities and microcosms in which people from another communities do not feel secure and at home. It seems that each part of the society is belonged to a special ethnic group and they feel a kind of patriotism toward that sector and other ethnic groups find themselves stranger and unwelcome.

Once Harry asks Willie to go to a restaurant in the soul neighborhood, but he declines his offer. Harry goes there alone and except for a red-dressed fat woman, "The other passers-by either ignore him or cut The Man with scornful jibes"

-Show-off cracker.

-Ofay spy.

-Goldberg hisself.

A stranger is a man who is called a stranger. Lesser, pleaing innocence, makes hasty plans for departure" (72).

In the opening scene of a short story that Willie gives Harry to read, there is a little black boy who finds himself in white neighborhood and cannot find his way back home. The book reads "Nobody spoke to him except an old white woman... (80)" Once again Malamud wanted to emphasize on the idea of being a stranger and lack of communication in such an atmosphere. The little black boy did not answer the lady's questions so she took him to the police saying that "He wouldn't answer the white pigs when they ask questions" (81). A little soon she comes to this conclusion that his not answering to the questions is because of her being white. It could be that, or for the fear of being a stranger in a strange neighborhood.

In an end-February-night Harry sees Bill and Irene with a gang of black boys and girls going to Mary's house to party. Bill invites Harry to "join the train" if he wants to, but Sam objects saying "What for this ofay type?" Bill tries to remind the gang of Harry's favor to him, but "None of the pairs made room for one more abreast and Lesser preferred not to walk with Sam, so he tailed the line to Mary's. He had met only one of the four people in the rear, the man with the light-skinned woman, Jacob 32, who nodded gravely with both eyes shut. The others ignored him but Lesser was glad to be with them, even as caboose to their train" (96).

It seems quite obvious that any ethnic group or minority finds itself right and flawless. When one finds a stranger helpful and kind he tries to attach him to his own ethnicity not to the stranger's. Harry leaves a bottle with six red and white carnations with a "Luck with your new book" note on a sheet of paper in his office. It is interesting to see that "Bill, perhaps embarrassed by the carnations, said nothing in the way of thanks for anything, except once he remarked there might be a diddle of black in Lesser's blood" (80).

Another example of this kind of prejudice regarding one's own ethnicity is the picture of a black Jesus hanging in Irene's bedroom. "In the bedroom stands a double bed, a picture of a black Jesus hanging on the wall above the headboard.

"Why a black Jesus?" Lesser asks.

"Willie won't let me hang any pictures of whites (109)".

Irene and Harry enter her apartment in order to dry her wet feet because her boots were leaking. Whether intentional or unintentional, it is interesting to see that "Irene removes her boots and dries her feet with a black towel as Lesser watches" (109). 
Once, Harry meets Irene, Willie's "white chick" in the street in a cold day. After drinking something warm they walk to the park. Harry begins asking questions about Irene and Willie friendship. She mentions to some interesting things regarding Willie and his blackness. "The blackness of him scared and excited me." History was always a burden on the shoulders of those who had a painful past. Although we know little about his childhood, it is shown in his short stories. She says that he spent two years in prison and changed his birthplace every time he was asked. It seems that he hates to remember it.

Another important thing regarding minorities is their awareness and self-consciousness of their being different which is bothering. Irene says that Outside of his love for black people I don't think he loves anything but his work. .... Willie was always conscious of his colour but it's more so now. The more he writes the blacker he becomes. We talk an awful lot about race and colour. A white chick is no longer such a hot thing for a black man, especially the activists. Willie won't let me hold his hand in public any more (93).

People from a special culture or ethnicity who share a common language or custom try to use that language or perform the custom or ritual, especially when they are in a foreign community and it is safe to use and to perform them in order to show intimacy and break the distance among the other members. They have a sense of prejudice and belonging, similar to nationalism, toward their community and ethnic members and try to protect them at the time of danger and calamity. Once Harry sees Irene in the street and says "shalom" when they see each other the other time she asks him the reason for using this word. Harry answers:

"I meant don't be a stranger."

"Be white? Be Jewish?"

"Be close is better."

“...I felt jealous of you and Bill when I saw you on Lexington Avenue."

She gazes into Lesser's eyes. "Are you in love with me because I'm Willie's Jewish white girl? I mean does that have something to do with it?"

"Maybe. I wouldn't say so."

"Do you want to save me from a miserable life with a black man, an ex-criminal?" (108)

Huntington, in his last book, Who Are We?, insists on language as a main boundary between the newcomersHispanics - and the American nation and criticizes the fact that the ones targeted as the Other share the same language, thereby endangering Anglo-Saxon conformity that has been defined as assimilation in America (Huntington, 2004).

Feeling sympathy toward another minority group is usually common among marginalized minorities. This kind of sympathy is rooted from their sharing and experiencing the same kind of injustice and discrimination and treated in the same way by the dominant super power in the society. Irene and Harry, both white Jews, fall in love but they both are worried bout how to let Willie face the news. Harry seems to be in hurry and asks Irene to tell Willie or let him talk to Willie or tell him together. But Irene tries to buy more time and let him finish his work. The important thing is what happens to Willie after he leaves here. He hasn't got two nickels to rub together. How's he going to live and write? I worry about that. Willie's struggle to be a writer from being in prison to actually writing the kinds of things he is, his stories and novel, is one of the most affecting things I know about anybody's life. It moves me an awful lot. He has to go on (114).

Though minority groups seem to dissolve in the dominant social structure of the society, they have their own territory within and try to keep it safe and clean. They prefer to be themselves in their small territory and keep away the strangers even if they are from the majority group. At the early stage of Willie and Irene's friendship he used to take her to the Harlem often "But after one of the brothers had talked to him privately-I think it was Jacob-he stopped inviting me and used to go by himself" (119).

Despite intense effort we make to treat every body the same way as if we are dealing with a colorless creature, there is something placed fixed in us which will be revealed once in order to express who we are and what we think of others, especially at the time of anger and rage.

After a deadly struggle between Willie and Harry over Harry's romance with Willie's girlfriend, Willie says that "What's wrong is I forgot to go on hatin you, whiteshit. Now I hate you till your death." It shows his hidden hatred toward him and that he hated him before, and after developing a kind of friendship between them he changed his mind or at least stopped thinking that way but now he returned to the first place, hating him.

The black goes on writing. Harry checks his trash to find what is he working on. On a few experimental pages 
titled 'Manifested Destiny' he faces something interesting. The first page was covered from top to bottom just by these two words 'black, white' the second 'black, whit' the third page 'black, whi' next 'black, wh' next page 'black, w' and finally ' black, black,...' This is the ending which the black character of the story believes in, a black world. This might be an ideal world for them, or maybe this is what they are promised and now they tolerate and suffer for the promised end.

When it comes the time of encountering the opposite sex or the way these two males think about girls Malamud airs a sense of doubt or even strangeness to the fact. Let me put it this way Harry has not have sexual relationship with a black girl before, so it seems for him as something strange or as a kind of new experience, that's why he wonders what it would be like to sleep with a black girl. As Edward said say in his Orientalism it can be inferred that Harry considered sleeping with a Jew girl as a usual social behavior but with a black girl something mystic or unusual. On the other hand Willie calls his white Jewish girlfriend "sweet bitch" trying to belittle or undermine her maybe for two reasons, since she is white not black and Jew not Christian.

At the Bennington memorial service for Malamud, Phebe Chao listed some of his interrogations: when he was writing The Tenants, 'Have you ever had sex with someone of another race?'; of a woman married to an older man: 'What was it like when your husband first kissed you?' 'I want to put this in a book' was the line Joan Gardner remembered him using, pen and notebook in hand, as he confronted some younger woman (Davis, 2007, p. 284).

Although Harry denies being jealous of Willie for having a white Jewish girl, Irene, it can be easy to understood that it has racial implication when he and Irene started cheating Willie; he says "...I have this awful feeling as though you and I are a couple of Charlies giving a nigger a boot in the ass" (148).

Much can be said about the language that the black character of the novel uses. Considering the idea that language can be a powerful indicator and signifier to show the difference, we can see that Willie uses a language rooted from the social reaction of the black race toward the language that the dominant power of the society uses. It is a conscious objection to the hegemonic power. Linguistic deviation can be detected approximately in every sentence he writes or utters. Mimic monkey is able to use the language properly and at the same time the way he wishes. He tries to use it in his own way to show his power and also his mastery on the other features of the language. Malamud, too, in order to indicate that blacks are considered as the stereotype of music and rhyme lets his character say: "Don't nobody have to tell me about rhythm" (87).

Three endings that can be counted for the novel each of which can be considered as a possible future of the relationship between the two marginalized social groups in the United States of America. The first ending which is apparently hopeful is a double wedding between Harry and Mary and Willie and Irene, or in other words, black and white-Jew will intermarry and solve the problem of racial conflict. This might be an ideal world for Bernard Malamud, where blacks and whites, Jews and Christians can marry and live peacefully with each other regardless of their color and what religious group they are from and the key factor that they establish their new life is love which is very important for Malamud and is a major theme in some of his novels and short stories. The ending containing descriptions of the interracial marriages also illustrates an aspect of the two writers' relationship, in this instance leading to a positive, highly optimistic, conclusion.

The second ending concludes a period in which Harry has destroyed Willie's typewriter, having found that his own paper gave off an unpleasant odor, that of hate. He has had a reverie of being destroyed in another fire, this time set by Willie. He now no longer writes; that is, he no longer attempts to find out about love. The building has become a jungle and each strikes the other in the place where his own group is most prone to being stereotyped, thus showing how much like the other each has become. So, Harry sinks an ax in Willie's brain, and Willie cuts off Harry's balls. Like the previous ending, this one is fantasy; it does not occur. The only hope is seen in the final phrase: "Each, thought the writer, feels the anguish of the other (230)." Of course, it is too late for this feeling to have an effect.

The final ending of the novel is Levenspiel's cry for mercy. Since the first ending is unlikely, the only way to avoid the second may be through Levenspiel's plea that black and white have mercy for each other as struggling fellow human beings. While some critics think this triple ending is inadequate, actually an avoidance of an ending, Malamud's provision of choice here mirrors reality. He admitted in an interview four years after the novel's publication: "It's impossible to predict - it may go one way; it may go another" (Field, 1975, p. 14).

In The Tenants, it becomes very clear that Willie Spearmint, who is filled with latent and often also very explicit anti-Semitic attitudes, will not be able to accept the Jewish cultural hegemony which Lesser offers at the beginning of the narrative. On the other hand, Lesser is not able to accept Willie's lifestyle and tolerate Willie's search for an autonomous black writing style (Spevack, 1997). 
Conversely, the Jewish prejudices against blacks become clear when the Jewish landlord Levenspiel notices that Willie has been illegally squatting in one of the apartments of his house. Levenspiel proceeds to ask Lesser: "Who's the gorilla in Holzheimer's old flat?" He also threatens: "Tell your nigger friend I'm coming back with a cop (73-74)."

Malamud set his work to show a small part of American society in this novel and indicate the conflict between the balcks and the Jews as two major American marginalized groups during 1960s. What made blacks an "Other" in the society was the physical features. If the physical signs act as signifiers, what they signify is the negative attitude and knowledge that the dominant culture acquired from the past, as they were mentioned earlier by biological racists and the idea of human hierarchy, and trying to make one race superior to other races.

Similar to what Jews did to blacks in America at the time, by supporting their causes for their rights, since Jews had the same condition and experienced similar discrimination and injustice, in this novel Harry is trying to help Willie to write his stories. But Willie does not accept his comment for improving the style.

In a psychological process people who had been considered as "Other" or inferior little by little come to internalize this kind of treatment. According the Yung in becomes the archetype of the nation. This notion can be traced both in Harry and Willie. In the one hand, Harry as a representative of the Jews, though from minority religious group, for being of white race had a feeling of superiority over Willie, the black character. The process of assimilation of Jews in American society was easier for being white and hard to single out. For the blacks it was rather impossible unless John Lennon's idea of "bagism" could be applied in society. In addition to being a white Harry felt superior over Willie because he had published a successful novel and he thought that he could teach Willie how to write.

Willie's self-conscious of being black and different, brought him to the verge of anger and made him take a defensive position. He told Harry that not only they are different in physical features, but also in language, style and form. So a white can never teach a black what and how to write.

The three possible endings suggested by Malamud can be the three possible future of modern society. A superficial peace and harmony by observing the human rights and treating every man equally and just regardless of their race or religion, while trying to hide the hatred and felling superior over others which became a part of our identity, history, and sub-conscious mind, or living in the world full of hatred, war, and brutality by expressing the feeling of superiority and right to power fueled by racial and religious difference.

\section{Conclusion}

Analyzing Bernard Malamud's The Tenants with the emphasis on the issue of racism and Othering it can be concluded that physical features such as skin color, shape of nose, shape of lips, size of skull, and type of hair are only a few noticeable signifiers that can make a person seem different in a community or society. The fact that how people who are spotted as Other in a community are treated badly has never been fixed, rather highly dependant to the time and place and the people directly involved with the issue.

Treating the other people influenced by their race and religion can be detected in every encounter and relationship in this novel from the most common one such as shaking hand to the most sensitive and private one such as having sex. Evidences indicate that the world has never been Utopia to home people with differences in peace; but the type and strictness of cruelty against Others might have changed during the time. The novel's three different endings might be considered as the possible alternative future relationship between people from different race or religion: 1 . Forget the past and the conflict and try to live with love in peace, 2 . Continue the everlasting debate and hatred, 3. Have mercy on each other. My emphasis is that even in modern time with considerable advances in science and technology and having educated and cultured people all around us discrimination and brutality against Others have not abolished but they appeared in new forms.

\section{References}

Davis, Philip. (2007). Bernard Malamud: A Writer's Life. New York: Oxford University Press.

Dennis Rutledge M. (Summer, 64, 3, 1995). Social Darwinism, scientific racism, and the metaphysics of race. The Journal of Negro Education, 243-252. Research Library Core. Retrieved from http://www33.homepage.villanova.edu/edward.fierros/pdf/Dennis,\%20Social\%20Darwinism.pdf

Dijk Teun A. Van. (Oct. Nov. Dec., 1992). Theses on the rise of European racism, and how to combat it. Socialist Studies Bulletin, 17-25. Retrieved from http://www.discourses.org/OldArticles/Theses\%20on\%20European\%20Racism.pdf

Fiedler, Leslie. (1977). "Negro and Jew" (1966). A Fiedler Reader (pp. 97-107). New York: Stain and Day. 
Field, Leslie A., \& Joyce W. (Eds). (1975). Bernard Malamud: A Collection of Critical Essays. Englewood Cliffs. New Jersey: Prentice Hall.

Huntington, Samuel P. (2004). Who Are We? The Challenges to America's National Identity. New York: Simon and Schuster.

Malamud, Bernard. (1972). The Tenants. London: Eyre Methuen.

Ozick, Cynthia (1975). Literary Blacks and Jews. In Leslie A. Field, \& Joyce W. Field (Eds.), Bernard Malamud: A Collection of Critical Essays (pp. 80-95). Englewood Cliffs: Prentice Hall.

Rattansi Ali. (2007). Racism: A Short Introduction. Oxford: Oxford University Press.

Spevack, Edmund. (Autumn, 1997). Racial Conflict and Multiculturalism: Bernard Malamud's The Tenants. MELUS, 22(3), 31-54. Varieties of Ethnic Criticism.

Stern, Daniel. (Spring 1975). The Art of Fiction: Bernard Malamud. Paris Review, 16, 40-64.

Note

Note 1 . Hereafter all the quotations from this book as primary source will come in parenthesis with page number. 